\title{
Differential Rate of Dry Rot in Dioscorea rotundata (White Yam) along the Tuber Length Due to Rot Causing Fungi
}

\author{
Apovughaye Taiga \\ Department of Botany, Delta State University, Abraka, Nigeria \\ Email: akpotaiga@yahoo.com
}

Received May 29, 2012; revised September 20, 2012; accepted October 3, 2012

\begin{abstract}
The susceptibility of different regions in Dioscorea rotundata (white yam) tuber to rot infecting fungi was investigated. Isolation was made from the periphery of the rotted tuber tissues, followed by a pathogenicity test and identification of isolates. Three fungi associated with $D$. rotundata (white yam) were isolated; they include Penicillium oxalicum, Aspergillus niger and Rhizopus stolonifer. Each of the isolates from pure cultures were inoculated on the head, middle and tail regions of healthy yam tubers. The three fungi were found to be pathogenic at different rates at the head, middle and tail ends of the yam tuber respectively. The head region was less susceptible to the three fungi with the following rot depths (P. oxalicum $25 \mathrm{~mm}^{\mathrm{a}}$, A. niger $18.2 \mathrm{~mm}^{\mathrm{a}}$ and $R$. stolenifer $\left.12.7 \mathrm{~mm}^{\mathrm{b}}\right)$. Rot depth in the middle region was $(P$. oxalicum $15 \mathrm{~mm}^{\mathrm{a}}$, A. niger $10.6 \mathrm{~mm}^{\mathrm{a}}$ and $R$. stolenifer $\left.8.8 \mathrm{~mm}^{\mathrm{b}}\right)$. While the tail region of the yam tuber recorded rot depth of (P. oxalicum $32.0 \mathrm{~mm}^{\mathrm{a}}$, A. niger $26.4 \mathrm{~mm}^{\mathrm{a}}$ and $R$. stolenifer $20.8 \mathrm{~mm}^{\mathrm{b}}$ ) respectively. Generally, the tail region of $D$. rotundatawas more susceptible to fungal attack and the rot recorded in the tail region was significantly different from rot at the middle and the head. It was recommended that yam tubers should be stacked with their head on the ground to reduce incidence of rotting in stock-piled yam tubers.
\end{abstract}

Keywords: Dioscorea rotundata; Tuber; Fungal Dry Rot; Head; Middle; Tail

\section{Introduction}

The word "yam" refers to the tuber of the botanical genus Dioscorea in the family Dioscoreaceae [1]. In Nigeria, Adamawa, Taraba, Benue, Nassarawa, Kogi, Edo and Kaduna states are the major yam producing states. Edible species of yam include $D$. rotundata Pour, $D$. cayennesis Lam; D. inspida Dennst; D. bulbiferaL; D. opposeta Thumb; and D. trifida Lare [2].

Nigeria, cultivates three edible species namely: $D$. rotundata Pour (white yam), D. cayenensis Lam (yellow yam) and $D$. bulbifera L. (Aerial yam); together with three other species namely: $D$. alata $\mathrm{L}$ (water yam), $D$. esculenta (Lour) Burk (Chinese yam) and D. dumenterum pax (Cluster yam) [3].

Dioscorea rotundata is a swollen tuber, a liana, which contain about eighteen different amino acids in smaller quantities ad mainly carbohydrates [4], a fact that makes it a major source of carbohydrate for most people in the world, especially Africans and Asians. The yam tuber could be prepared into a number of forms; it could be boiled and pounded into "fufu", porridge, roasted or mashed. In the Niger-Delta of Nigeria, it is cooked into a delicacy known as "ukodo" (yam and pepper soup) that is usually used for marriage and burial ceremonies or as breakfast, particularly during the cold season. It could also be processed into flour. Itcan also be fried into chips or flakes, which are excellent food for most people [5]. Cultivation of $D$. rotundatahas offered employment to farmers and traders in the region. Its subsistent production level augments the incomes of most families. The yam peelings also form part of household waste use in feeding livestock [6].

Idah local government area in Kogi State is one of the major producers of white yam in Nigeria. The area lies along the coast of Rivers Niger and Benue; with a total rainfall of about $1500 \mathrm{~mm}$ per annum and a characteristic clayey-loamy soil which avail the yam a good environment to thrive.

The occurrence of a large number of $D$. rotundata cultivars in eastern Nigerian [7], lends support to the belief that $D$. rotundatais native to Nigeria; with most probable place of origin as the eastern bank of the River Niger where it is still the preferred food crop [8,9]. In this region, yam is not only an important stable food; it is considered a man's crop. It has rituals and socio-cultural significance; it is the food of choice at many ceremonies and festivals, and an indispensable part of bride price [8]. New yam festivals are celebrated annually, during the months of August and September, in eastern Nigeria.

The white yam $(D$. rotundata) is produced in large 
quantities and often stored for use later. Unfortunately, considerable amount of the tubers get rotted during storage. Post-harvest losses of yams alone account for about 7 million tonnes out of the world's total production of 27.08 million tonnes [10].

In Nigeria, post-harvest bio-deterioration of yam tubers resulting in microbe-induced rot is one of the most important factors militating against commercial production of yam [11].

The problems associated with yam tuber start from the field. During harvest, most of the tubers are bruised or damaged, thereby predisposing them to microbial attack that could cause rot during storage. Each year, appreciable tonnes of harvested tubers are lost to microbial attack, especially fungi and bacteria [12].

Microbial infection has been reported to be rapid and severe where temperature and relative humidity favours their growth and enzyme production [13]. Considerable number of yam farmers has shown that fungal attack on yam occurs through injuries on the tuber [14]. A freshly injured yam rapidly loses moisture from the injured area leaving the injured site dry and become impervious to the hyphae of growing fungi; but the development of the protective coat on the injured site takes time. It is within the time of formation of this impervious coat that airborne spores of rot-causing fungi settle and grow on such injuries.

Many fungi have been identified by various workers as causal organisms of various yam diseases [12,15-17] isolated Colletotrichum gloesporioides as a fungal pathogen infecting minisettes through infested tubers. Botryodiplodiatheobromae, Aspergillus niger, A. tamarii, Cladosporium herbarum, Cylindrocapus radicola, Gleiocladium roseum, Geotrichum candidum, Gliomatrixconvulata, Macrophominaphaseoli, Mucorcircineloides, Fusarium moniliforme, F. solani, Penicillium cyclopium, $P$. sclerotigenum, Rhizoctonia solani, Rhizopus nigricans, $R$. stolonifer, and Rosellina spp. are other fungal pathogens associated with rots of yam tubers [18].

This research is aimed at identifying the various fungi associated with dry rot of $D$. rotundata in the area, and to determine the portion of the tuber that is more susceptible to fungal attack.

\section{Materials and Methods}

Rotted and clean yam tubers (D. rotundata) were purchased from Idah market, washed under running tap water and allowed to dry, observed under a binocular for possible dry rot signs, before about $0.5-1 \mathrm{~cm}$ pieces were cut at the periphery of the rotted tissues with the aid of sterile scalpel. Potato Dextrose Agar (PDA) was the medium used.Fresh potatoes were peeled, washed before $250 \mathrm{~g}$ were weighed and boiled for 30 minutes in 1 litre of tap water in a clean pot. The infusion was filtered and allowed to cool. To the infusion, $20 \mathrm{~g}$ of agar-agar and 15 $\mathrm{g}$ of dextrose were added. The infusion was made up to 1 litre with distilled water before the medium was autoclaved at $1.02 \mathrm{~kg} / \mathrm{cm}^{3}$ pressure for 15 minutes. Six millilitre $(0.1 \%)$ of streptomycin was added to the 1 litre of the sterilized media just, before pouring into Petridishes, to prevent the growth of bacteria.

The cut pieces were plated two per Petri-dish and incubated at room temperature for five days after sterilization in $2 \%$ sodium hypochlorite for 30 seconds and rinsed in three changes of sterile water. Pure culture of each isolate was maintained by aseptic transfer to a freshly prepared medium. Wet mount of isolate in latophenol in cotton blue were microscopically examined and identified on the basis of characteristic spores with reference to illustrated general of imperfect fungi [19] Pathogenicity test of each fungi isolate was carried out based on Koch's postulate using the method described by [20].

Susceptibility of yam regions to fungal attack was carried out by taking cylindrical cores of $1 \mathrm{~cm}$ deep aseptically from the "head", "middle" and "tail" regions of each yam tuber with a $5 \mathrm{~mm}$ cork-borer. Four millimeter disc of 7 days old fungal cultures were placed, fungus first into the holes in the tubers, before the cores of the yam from the tubers were replaced after about $2 \mathrm{~mm}$ have been cut off to compensate for the thickness of the Agar inoculums. Petroleum Jelly was used to cover the replaced cores to prevent contamination. Each experiment for the tuber regions was replicated three times. Controls were inoculated with plank sterile agar and all inoculated tubers were incubated at room temperature for four weeks; after which they were sliced through the site of inoculation and rot depth measured.

\section{Results and Discussion}

Various workers have identified many fungi as causal organisms of various yam diseases [17,21-24]. In this research, three fungal pathogens $(P$. oxalicum, $A$. nigerand $R$. stolonifer) were isolated and identified from rotted white yam (D. rotundata) in Idah Local Government Area in Kogi State. These fungi were pathogenic and they were responsible for the dry rot of yam in the area (Table 1).

Fungal dry rot of yam tuber in storage in Idah LGA (one of the major yam producing area in Kogi State) has led to loss of yam quality and quantity and consequently financial loss to farmers in the area. This confirmed the earlier reports by $[25,26]$; that post-harvest biodegradetion of yam tuber is one of the most important factors militating against commercial production of yams in $\mathrm{Ni}-$ geria.

- Data are means value;

- Means with the same alphabet along vertical rows 
Table 1. The results of the susceptibility test.

\begin{tabular}{ccccc}
\hline \multirow{2}{*}{ Fungi } & \multicolumn{4}{c}{ Rot depth average in $\mathbf{~ m m}$} \\
\cline { 2 - 5 } & Head region & Middle region & Tail region & Control \\
\hline Penicillium oxalicum & $15.0^{\mathrm{a}}$ & $25.0^{\mathrm{a}}$ & $32.0^{\mathrm{a}}$ & - \\
Aspergillus niger & $10.5^{\mathrm{a}}$ & $18.2^{\mathrm{a}}$ & $26.4^{\mathrm{a}}$ & - \\
Rhizopus stolonifer & $8.8^{\mathrm{b}}$ & $12.7^{\mathrm{b}}$ & $20.8^{\mathrm{b}}$ & - \\
\hline
\end{tabular}

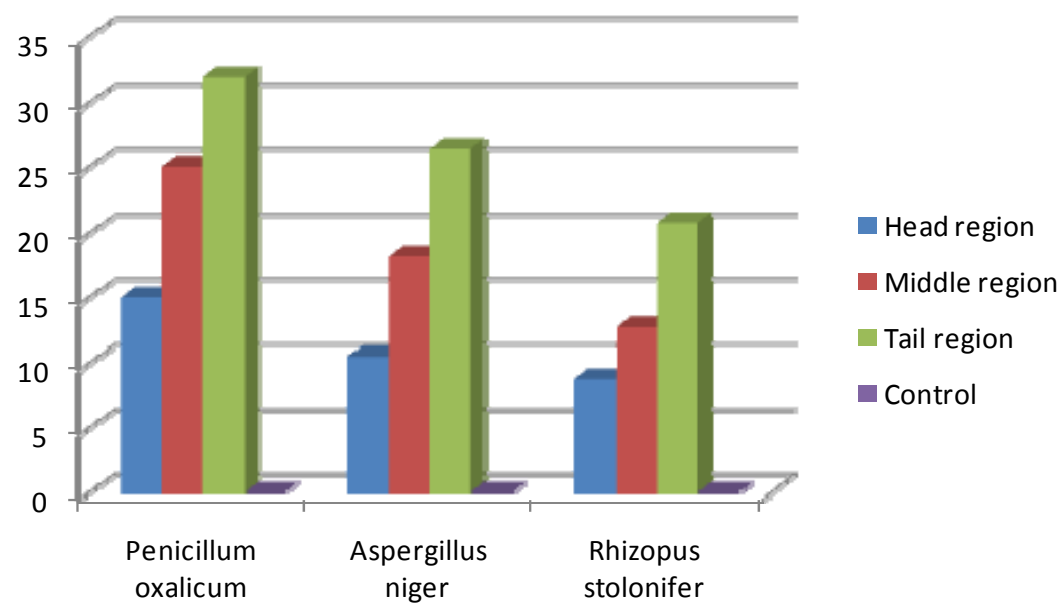

Figure 1. Rate of dry rot in Dioscorea rotundata (white yam) along the tuber length due to rot causing fungi.

shows no significant level (Duncan's multiple range test).

The tail region of the yam tubers showed higher susceptibility to the fungal pathogens $(32.0 \mathrm{~mm}, 26.4 \mathrm{~mm}$ and $20.8 \mathrm{~mm}$ ) for $P$. oxalicum, A. niger and R. stolonifer respectively; these results were significantly different from the result gotten from the middle and the head regions. Although the susceptibility of the middle region was less than that of the tail region, by the three fungi isolates $(25.0 \mathrm{~mm}, 18.2 \mathrm{~mm}$ and $12.7 \mathrm{~mm}$ ) for P. oxalicum, $A$. niger and $R$. stolonifer respectively; and this result was still higher from those observed at the head region $(15.0 \mathrm{~mm}, 10.5 \mathrm{~mm}$ and $8.8 \mathrm{~mm})$ for $P$. oxalicum, $A$. niger and $R$. stolonifer respectively; however, but there was no difference in susceptibility of the middle and that at the head regions (Figure 1).

Based on the observation from this research, farmers and traders are advised to take precautions during stacking of yam tubers in ware-houses not to stand them on the tail region as this could provide an easier way of exposing the tubers to injury and consequent rapid infection.

\section{REFERENCES}

[1] L. M. Degras, “The Yam. A Tropical Root Crop,” The MacMillan Press, London,1993, pp. ix-xi.

[2] I. C. Onwueme, “The Tropical Tuber Crop,” John Wiley and Sons, Hoboken, 1978, pp. 28-56.
[3] FAO, "The Role of Roots, Tubers and Plantains in Food Security in Sub-Sahara Africa, Latin America and the Caribbean, and in the Pacific (FAO Social and Economic Development Study),” FAO, Rome, 1989, p. 75.

[4] M. N. Suleiman and S. Adeyemi, "Isolation of B. theobramae from Yam Rot and Its Control Using Selected Chemicals," Savanna Journal of Science and Agriculture, Vol. 1, No. 1, 2002, pp. 53-60.

[5] I. C. Onwueme, "Strategies for Increasing Cocoyam (Colocasiae sculenta) and Yam (Dioscrea spp) in Nigeria Food Basket," Proceedings of 1st National Workshop on Cocoyam, Umudike, 16-21 August 1989, pp. 35-42.

[6] A. C. Amadioha, "Control of Powdery Mildew of Pepper (Capsicum annum L.) by Leaf Extracts Carica papaya," Journal of Herbs, Spices and Medicinal Plants, Vol. 6, 1998, pp. 41-47. doi:10.1300/J044v06n02_05

[7] D. G. Coursey, "The Origin and Domestication of Yams in Africa,” In: J. R. Harlan and J. M. J. de Hague, Eds., Origin of African Plant Domestication in Africa, The Hague, Mouton, 1976, pp. 383-403. doi:10.1515/9783110806373.383

[8] S. K. Hahn, D. S. O. Osiru, M. O. Akoroda and J. A. Otoo, "Yam Production and Its Future Prospects," Outlook on Agriculture, Vol. 16, 1987, pp. 105-110.

[9] G. C. Okwor, "Yam Production, Cropping Systems, Ecology, Development and Research in Nigeria,” Paper Presented at the National Seed and Plant Quarantine Project, 1992.

[10] A. Solape, O. Adeyanju and T. Ikotun, "Microorganisms Associated with Mouldings of Dried Yam Chips and Their Protection,” Die Nahrung, Vol. 32, No. 8, 1988, pp. 
77-78.

[11] O. C. Nwaorgu, F. I. Onyenobi and D. J. Wright, "Chemical Control of Yam Biodeterioration,” In: G. Osunji, Ed., Advances in Yam Research, Biochemical Society of Nigeria in Collaboration with Anambra State, 1985, pp. 261-276.

[12] A. Taiga, "Varietal Resistance of Yam (Dioscorea spp) Tubers to tuber Infecting Fungi," Inter-World Journal of Science and Technology, Vol. 2, No. 1, 2003, pp. 174181.

[13] S. K. Ogundana, D. T. Coxon, C. Denis and S. H. Z. Nagvic, "Natural Antifungal Compounds from the Peel of Yam Tubers," Proceedings of the 6th Symposium of the TRC International Potato Center, 1980, p. 616.

[14] P. Ricci, J. P. Torregrossa and R. Armolin, "Storage Problems in Cush Yam I. Post-Harvest Decay,” Tropical Agriculture Trinidad, Vol. 56, No. 1, 1979, pp. 41-48.

[15] A. Taiga, "Effect of Relative Humidity (RH) on Yam Tuber Infection by Rot Causing Fungi,” Learned Journal of Science, Agriculture and Engineering, Vol. 1, No. 1, 2006, pp. 80-82.

[16] A. Taiga and D. B. Olufolaji, "In Vitro Screening of Selected Plant Extracts for Fungicidal Properties against Dry Rot Fungi of Yam Tuber (Dioscorea rotundata) in Kogi State, Nigeria,” International Society Biotechnology Conference, Majitar, 28-30 December 2008, pp. 309-311.

[17] A. Adebanjo and P. J. Onisirosan, "Surface Borne Infection of Dioscorea alata Tubers by Colletotrichum gloeosporioides," Journal of Plant Protection in the Tropics, Vol. 3, No. 2, 1986, pp. 135-137.

[18] A. C. Amadioha, "Fungitoxic Effect of Some Leaf Ex- tract against Rhyzopus oryzae Causing Tuber Rot of Potato," Activities of Phytopathology and Plant Protection, Vol. 33, 2006, pp. 499-507.

[19] H. L. Barnett and B. B. Hunter, "Illustrated Genera of Imperfect Fungi,” 3rd Edition, Burgess Publications Co., Minneapolis, 1972, p. 299.

[20] N. Okafor, "Microbial Rotting of Stored Yams (Dioscorea spp) in Nigeria," Experimental Agriculture, Vol. 2, 1966, pp. 179-182. doi:10.1017/S0014479700026697

[21] S. Prasenjit, "Chemical Control of Dioscorea Tuber Rot Caused by Fusarium solani during Storage,” India Journal of Phytopathology, Vol. 34, No. 4, 1984, pp. 621-722.

[22] T. Ikotun, "Microbial Rot of Tubers of Chinese Yams, (D. esculenta) in Storage," Fitopatologia Brasileira, Vol. 11, 1986, pp. 241-244.

[23] Anon, "Root and Tuber Storage Programme," 23rd Annual Report of Nigerian Stored Products Research Institute for 1986, Lagos, 1991, p. 9.

[24] B. O. Ejechi and M. E. Ilondi, "Control of Yam Tuber (Dioscorea rotundata) Rot Agent Sclerotium rolfsii with Camwood (Baphidanitida Lodd) Sawdust Extrat," African Journal of Root and Tuber Crops, Vol. 3, No. 2, 1999, pp. 13-15.

[25] T. Ikotun, "Post-Harvest Microbial Rot of Yams in Nigeria,” Fitopathologia Brasileira, Vol. 8, 1983, pp. 1-5.

[26] O. C. Nwaorgu, F. I. Onyenobi and D. J. Wright, "Chemical Control of Yam Biodeterioration,” In: G. Osunji, Ed., Advances in Yam Research, Biochemical Society of Nigeria in Collaboration with Anambra State, 1985, pp. 261-276. 